Revista de la red interuniversitaria de estudios sobre las literaturas rioplatenses contemporáneas en Francia

\title{
“El siglo XIX y ¿yo?”
}

\section{Néstor Ponce}

URL: http://journals.openedition.org/lirico/1692

DOI: $10.4000 /$ lirico. 1692

ISSN: 2262-8339

Editor

Réseau interuniversitaire d'étude des littératures contemporaines du Río de la Plata

Referencia electrónica

Néstor Ponce, " "El siglo XIX y ¿yo?" », Cuadernos LIRICO [En línea], 10 | 2014, Puesto en línea el 15 marzo 2014, consultado el 20 abril 2019. URL : http://journals.openedition.org/lirico/1692 ; DOI : 10.4000/lirico.1692

Este documento fue generado automáticamente el 20 abril 2019.

\section{(c) $(1) \Theta \Theta$}

Cuadernos LIRICO está distribuido bajo una Licencia Creative Commons Atribución-NoComercialSinDerivar 4.0 Internacional. 


\title{
"El siglo XIX y ¿yo?"
}

\author{
Néstor Ponce
}

1 En mi trabajo de escritura he recurrido de manera constante a tres materiales: la memoria, el lenguaje, la imaginación. No concibo a uno/a sin el/la otro/a.

2 Cuando hablo de memoria, aludo no sólo a la ligereza desgarradora de la individual, sino también -sobre todo en algunos textos- a la furiosa puntualidad de la colectiva. Habrán entendido que se trata de escribir desde la derrota, desde la impotencia, desde el dolor. De por sí, escribir es un signo de impotencia, de imposibilidad. Un ademán inútil que lleva siempre al fracaso.

3 Con la memoria colectiva he procedido a un trabajo de reconstrucción, que pasa obviamente por un proceso de documentación, de archivo, de investigación y de invención de las lenguas del periodo, de los diferentes imaginarios- en particular la del otro denegado y convertido en monstruosidad. Pero que es sobre todo un capítulo de un viaje que se va armando en la tarea de la escritura.

4 Tal vez haya aquí, y es sólo una hipótesis, otra forma de memoria individual : rescatar los momentos de descubrimiento, de fascinación, de aventura, que fueron en mi infancia y en mi adolescencia la lectura de libros que me hicieron viajar, flotar, desvanecerme y volverme a reconstruir para ser más entero y para ser mejor. Esas lecturas eran un desafío ante la dificultad árida y agresiva de poder elaborar uno mismo esos mundos imaginarios.

5 En ese terreno, el siglo XIX ha sido muy a menudo para mí un hilo conductor para comprender y para interrogar al presente. ¿Por qué el XIX? Porque determina y explica la Argentina, en particular en la última etapa, la que gira en la órbita de la generación del 80. De allí venimos, ahí fue cuando nos malogramos y nos jodimos, como hubiera dicho Vargas Llosa. ¿Hubiéramos sido menos civilizados y más bárbaros si no hubiera habido la Conquista del desierto? ¿Hubiéramos sido mejores?

6 Varios de mis textos transcurren en el XIX : las novelas El intérprete (1998), La bestia de las diagonales (1999), Una vaca ya pronto serás (2005), el cuento "El signo de la pus" (2004), la nouvelle "Sous la Pierre mouvante" (2009). Azote (2008) se desarrolla a mediados del siglo XXI e Hijos nuestros (2004) en los años 1990. Pero ambos son deudoras del pasado. 
7 En todos estos textos, evocándolos desde la dificultad del ombligo, creo haber buscado una forma de memoria, una manera de cepillar la historia a contrapelo.

8 El siglo XIX y yo. Ahora, quisiera escribir un nuevo libros de poemas partiendo de la historia. Algo así como un recorrido argentino desde la época de la primera fundación hasta ahora. El siglo XIX tendría, en ese poemario imposible e imaginario, una gran plaza. El siglo XIX y yo. Eso. 